\title{
The Implementation of Cooperative Training in Technical and Vocational Education and Training Colleges of Oromia
}

\author{
Tolla Berisso Geda \\ College of Business and Economics, Arsi University, Asella, Ethiopia
}

Email address:

tolla.berisso@yahoo.com, Presidentau829@Gmail.com

\section{To cite this article:}

Tolla Berisso Geda. The Implementation of Cooperative Training in Technical and Vocational Education and Training Colleges of Oromia. Education Journal. Vol. 5, No. 4, 2016, pp. 43-48. doi: 10.11648/j.edu.20160504.11

Received: May 15, 2016; Accepted: June 2, 2016; Published: June 21, 2016

\begin{abstract}
The intent of this study was to examine the extent of the implementation of cooperative training in Technical Vocational and Education and Training Colleges of Oromia, Ethiopia. To achieve this purpose, researcher used mixed research design, quantitative and qualitative. The participants of the study for quantitative data includes: 77 (36.73\%) trainers, 49 (48.89\%) leaders and 74 (23.44\%) level-4, 2014 trainees a total of 200 respondents and 1 TVET agency outcome based training process owner, 6 District TVET representatives, 6 Deans, 6 outcome based TVET colleges process owners and 6 industry representatives to obtain qualitative data. Quantitative data obtained were analyzed by applying descriptive statistics (i.e., mean, standard deviation and percentage) and inferential statistics (One-way ANOVA) and the qualitative data was analyzed with the help of themes to view a clear picture of the issue understudy. The study result showed that their exist weak collaborative work culture among TVET colleges and that of industries and TVET colleges under the study did not adequately sorted out potential industrial partner and established full collaboration with them. Hence, the study recommended the importance establishing and maintaining networks of partners for the delivery of cooperative training, feedback on the quality of TVET programs and facilitating the employment opportunity of TVET graduates.
\end{abstract}

Keywords: Cooperative Training, Industry, Implementation, TVET Colleges

\section{Introduction}

Sustainable economic development and Education and trainings are interdependent. Economic development cannot take place without the development of human resources. It is believed that education and training liberate citizens from ignorance and acquaints them with modern civilization to pave the way for further development and prosperity as well. Therefore, well-qualified professionals must be trained in order to raise the competitiveness of companies, countries, and regions [2]. Although the development of human resources through TVET is not the only condition for economic and social development, it can make a crucial contribution to it.

In this regard, the primary objective of technical and vocational education and training (TVET) program is the delivery of relevant knowledge, practical skills and attitudes for gainful employment in a particular trade or occupational area. Skill acquisition is vital for an economic competiveness and growth in an era of economic integration and technological change. Skill needs are wide spread in most developing countries - they are not only demanded by the modern wage sector but also by the agricultural and informal sectors. TVET is a direct means of providing workers with skills more relevant to the evolving needs of employers and the economy [3].

Besides, TVET program plays an essential role in promoting a country's economic growth, poverty reduction as well as ensuring the social and economic inclusion of marginalized countries [4]. To achieve this purpose, there must be a shift from traditional TVET delivery which focuses on learning process within specified times to outcome-based TVET program which is concerned with the demonstration or provision of evidences of knowledge, skill and attitude to a specific level of competences that is adapted to a country's socio-economic context and to worldwide technological development.

Technical and Vocational Education and Training (TVET) programs designed mainly to prepare students for direct entry into a particular occupation or trade, or class of occupations 
or trades. [6] The flexibility of TVET delivery also allows for a strengthening and further development and deepening of cooperative training. Cooperative training is a mode of training provided in partnership between enterprises and TVET institutions. The major advantage of cooperative TVET delivery form is its vicinity to the world of work.

The objectives of cooperative training is to educate and train effectively and cost-efficiently a workforce which possesses the competencies needed on the labor-market; to bring stakeholders together to work on the provision of suitably qualified manpower; to encourage enterprises to participate in the training process voluntarily and regularly in their own interest, to gain a qualified workforce and at their own expense, and to motivate participating enterprises to assign experienced trainers to plan and supervise training in order to maintain and increase their competitiveness and performance in an ever-changing market. This issue is crucial for the trainees' future employability, and it is best to be learned in the enterprises themselves.

Cooperative training familiarizes TVET trainees to the actual working atmosphere and enables them to develop the required skills and competencies that demanded by enterprises. In other words, it increases the employability of the trainees after completion of the necessary technical and vocational trainings appropriately. Within this context, cooperative training methods are seen as tools that enable occupation related knowledge and a skill to be passed and ensure that apprentices learn about the way that industries work is structured [5]. To make smooth transition from school to work TVET cooperative system must establish deep-seated links with stakeholders. Hence, the intention of this study is to examine the implementation of Cooperative training in Oromia Regional State.

\section{Statement of the Problem}

The TVET system in Ethiopia is currently being fundamentally reformed. A new TVET strategy has been disclosed which emphasizes the importance of TVET being oriented towards the skills needs of the Labor market. The TVET development as envisaged in reform strategy relies on solid private-public partnership and on dedicated cooperation between stakeholders [9]. It defines the framework for the implementation of cooperative training and the integration of enterprise-based training. Since the reformed TVET system is outcome based, it allows flexibility in the actual training delivery process. Public and private TVET providers are free to choose how best to organize TVET for their target groups according to requirements of Labor market in their respective regions [7].

According to the national annual [10] and other documents in the following opportunities are in place for the proper implementation of cooperative training. These are: increase in investment, availability of different projects and expansion of cottage industries which result from economic development of the country and create a demand for graduates and also places for training of TVET trainee'; availability of micro and small enterprises; the commitment and active participation of some trainers, professionals, leaders and stakeholders; the existence of TVET council and TVET board at regional and TVET college level respectively; the existence of TVET Policy, Strategy and different guide lines and frameworks and due to attention given by national government to the cooperative training. Besides, different working documents such as new cooperative training manuals, guidelines, directives, legal frameworks etc. are prepared and implemented to improve the performance, efficiency and output of the system; community perception and attitude has to some extent improved that can be confirmed by the growing number of people who are benefited from cooperative training; etc and the establishment of TVET as separate entity, TVET Agency, with autonomy will help to get focus.

However, there are various constraints on the implementation of the cooperative training. In this regard, the researcher have tried to informally discuss with experts in the area and examine Regional annual TVET performance evaluation report and recognizes that the training delivered mostly did not yet pay adequate attention to those junior workers who are unskilled; still there is mismatch between the labor market and the training delivered that ultimately has resulted is producing skilled unemployed graduates. Besides, studies have shown that many TVET graduates remain unemployed even in those occupational fields that show a high demand for skilled manpower. Furthermore, substantial resource wastages occur as a result of underutilization of equipment in public TVET institutions. This compounded by the poor stakeholder partnership, where trainees are not adequately exposed to the appropriate work environment.

Hence, the main purpose of this study was, therefore, to investigate the challenges and opportunities of cooperative training implementation in TVET Colleges of Oromia Regional State. To this effect, the study will attempt to answer the following basic questions.

1. To what extent TVET colleges in Oromia implement cooperative training?

2. What are the challenges that hinder the implementation of cooperative training?

\section{Research Methodology}

The empirical investigation is based on the mixed research design, quantitative and qualitative. Moreover, the study was delimited to $6(33.3 \%)$ TVET colleges found Oromia Region. Besides, to address the raised research question, the researcher prepared questionnaires for 77 (36.73\%) trainers, 49 (48.89\%) leaders and 74 (23.44\%) level -4, 2014 trainees a total of 200 respondents. The data obtained were analyzed by applying descriptive statistics (i.e., mean, standard deviation and percentage) and inferential statistics (One-way ANOVA). Besides, interview and focus group discussion conducted to collect qualitative data from 25 informants that include: 1 TVET agency outcome based training process owner, 6 District TVET representatives, 6 Deans, 6 outcome based 
TVET colleges process owners and 6 industry representatives. Finally, the qualitative data was analyzed with the help of themes to view a clear picture of the issue understudy.

\section{Result and Discussion}

In the Table 1 below, an attempt was made to assess the extent of the implementation of held between TVET colleges and enterprises. Questionnaires regarding the above issue were raised for TVET trainers and leaders respondents. An assessment has been made by using a five point scale ranging from not at all, to frequently, if not always. Accordingly, respondents rate their response on each item as follows.

Table 1. Responsibilities executed by TVET colleges.

\begin{tabular}{|c|c|c|c|c|c|}
\hline \multirow{2}{*}{ No } & \multirow[b]{2}{*}{ Items } & \multicolumn{4}{|c|}{$\mathbf{N}=\mathbf{2 0 0}$} \\
\hline & & Mean & SD & $\mathbf{F}$ & Sig. \\
\hline 1 & $\begin{array}{l}\text { Curricula considers local labor } \\
\text { market requirement }\end{array}$ & 1.90 & 1.03 & 3.43 & .009 \\
\hline 2 & $\begin{array}{l}\text { The development of TVET } \\
\text { curriculum is based on the national } \\
\text { occupational standards }\end{array}$ & 1.91 & .85 & 2.680 & .031 \\
\hline 3 & $\begin{array}{l}\text { Training modules describes an } \\
\text { employable set of competencies }\end{array}$ & 1.77 & .80 & 1.243 & .292 \\
\hline 4 & $\begin{array}{l}\text { The bulk of practical training takes } \\
\text { place in an enterprise }\end{array}$ & 2.44 & 1.10 & 1.996 & .095 \\
\hline 5 & $\begin{array}{l}\text { Vocational counsellors facilitate } \\
\text { cooperative training }\end{array}$ & 2.56 & 1.34 & 6.675 & .000 \\
\hline 6 & $\begin{array}{l}\text { Trainees are interested on cooperative } \\
\text { training in the enterprise }\end{array}$ & 1.53 & .83 & .915 & .455 \\
\hline
\end{tabular}

The relevancy of any training and its curriculum is determined heavily by the extent it meets the ultimate educational and training objectives and the degree it gears towards the socio-economic needs of the country. Specifically, an outcome-based curriculum is a framework or guide that specifies outcomes which are consistent with the requirements of the workplace as agreed through the industry or community consultations. Connected with this first and second items of Table 1 indicates the relevance of institutional-based curriculum to local labor market needs and national occupational standards.

As it can be observed from the data the current TVET curriculum that developed at TVET college level not sufficiently consider local labor market requirements and national occupational standards with grand mean 1.90 and 1.91 respectively. Concerning this issue, it is so as per the three TVET college deans participating on FGD, as have been explained, due to low competence of trainers to develop curricula that satisfy the need of the labor market and follow national occupational standards. From this it is possible to conclude that outcome-based TVET reform implementation may, negatively, be affected by less relevance of TVET curriculum. In such cases, there exists a mismatch between the supply of education and training and the requirements of the labor market.

For items 1 and 2, the analysis disclosed that there were statistically significant differences in mean scores between trainers $($ Mean $=1.65$ and 1.77$)$, on the one hand, process owners and board members (Mean $=2.04$ and 2.24) respectively, on the other hand on relevance of curriculum to labor market needs and occupational standards. Such differences may occur due to the dissimilarity on the actual practices among trainers and administrators.

Outcome-based TVET provides high flexibility in the way TVET can be delivered. Hence, the modularization of TVET is a central mechanism of making TVET delivery flexible and providing for flexible entry and exit point [7]. In this regard, individual TVET colleges have responsibility to organize TVET programs in a modular fashion to meet the requirements as defined in the occupational standards. However, as can be seen in the above table, item 3, TVET colleges have not adequately develop modules for each unit of competences $(\mathrm{MoE}=1.77)$. This implies that training given lack important element that could help to address the expected outcome to the respective target groups. It is also a cause for unemployment in particular and the prevalence of poverty in general.

Item 4 deal with delivery of training program. Accordingly, respondents replied that time spent in industry less than time spent in TVET colleges with grand mean 2.44. During interview session, two industry representatives conform as trainees were not spent much time in their industry. Some of the reasons were: lack of awareness and interest, low advocacy and mobilization. During interview session two outcome based process owners indicated that micro and small enterprises were actively participated in cooperative training. Added to this, during FGD three Deans and two District TVET office representatives replied that the appropriate place for practical trainings are micro and small enterprises. The ANOVA test result for item 3 and 4 indicates that the non-existence of perception differences between groups of respondents.

The involvement of vocational counselor in the implementation of cooperative training is very essential. As stated in [12], the main responsibility of vocational counselor, as staff member, is monitoring, assisting, facilitating and coordinating cooperative training in enterprise and ensures that the institutional-based competencies are learned in accordance with the training plan. Concomitant with this, item number 5, also, deals with role played by vocational counselor in the implementation cooperative training and the majority of respondents reported that the participation of vocational counselor in cooperative training was average $(\mathrm{MoE}=2.56)$.

This implies that facilitation of cooperative training by vocational counselor in the respective college was not up to the expectation (Mean $=2.56$ ). On top of this, interview conducted with regional TVET Agency and TVET college outcome-based process owners reveals that in previous years there was no such strong cooperation and facilitation held by vocational councilors. The ANOVA test result and Tukey HSD for this item indicates that the existence of perception differences between trainers (Mean $=1.33$ ) and administrators (Mean $=2.91)$, on the one hand, and graduates $($ Mean $=2.22)$ and trainees $($ Mean $=2.14)$ on the other. These differences might be due to be proximity vocational councilors have with each group of respondents. 
As can be seen from the item 6, respondents seem to perceive trainees attitude towards cooperative training negatively $($ Mean $=1.53)$. But trainers response for openended items revealed that trainees come to industries with poor orientation, poor work ethics, as a result non-punctuality of trainees frequently occurs during the training program. Besides, industries did not assign training coordinator who passes occupational assessment. This might hinder successful implementation of TVET reforms.

In this regard, the first industry representatives during interview session indicated that "trainees are less interested on cooperative training in the enterprise. This is because they do not show a sense of responsibilities as a whole. Contrary to the above idea, the second interviewee has said that "trainee's attitude towards TVET system showing change from time to time". However, the third interviewee supports the first interviewee and said "few trainees dislike cooperative training; they frankly speak to industry supervisors and trainers as they are not interested on the occupation and as it was not their first choice, explaining they came only to get evaluation paper. Such trainees spent most of their time at staff lounge, or inside the work shop by trying to learn new features out of their cell phone".

The fourth industry representative said "trainee's attitude towards TVET system and cooperative training found to be changed from time to time, but, still some attitude related problems are revealed. Some trainees want to get signed final evaluation papers from industry/cooperative training providers without participating during cooperative training. Besides, some trainees become absent continuously from training, and some come to the industry very late. However, some diligently follow the training. Moreover, most TVET institutions look for and facilitate the cooperative training program to their trainees, but some TVET collages simply send trainees with letter to search cooperative training provider by the selves. This is also another problem. Trainees come in groups, seeking for cooperative training, shouting, wandering here and there without considering the trend and culture of the organization; they request to be on the same organization for their cooperative training".

Table 2. Responsibilities executed by Enterprises.

\begin{tabular}{llllll}
\hline No. & Items & Mean & SD & F & Sig. \\
\hline 1 & $\begin{array}{l}\text { Industries accommodate trainees } \\
\text { for cooperative training }\end{array}$ & 1.71 & .89 & 17.982 & .000 \\
2 & $\begin{array}{l}\text { Industrial trainers follow unit of } \\
\text { competences }\end{array}$ & 1.77 & .80 & 1.243 & .292 \\
3 & $\begin{array}{l}\text { Enterprises provide supervision to } \\
\text { train the trainees }\end{array}$ & 1.94 & .90 & 3.483 & .008 \\
4 & $\begin{array}{l}\text { Enterprises provide facilities to } \\
\text { train the trainees }\end{array}$ & 1.91 & .85 & 2.680 & .031 \\
5 & $\begin{array}{l}\text { Enterprises provide range of work } \\
\text { to train the trainees }\end{array}$ & 1.92 & .88 & 1.453 & .216 \\
6 & $\begin{array}{l}\text { Industry trainer evaluates the } \\
\text { trainee's progress }\end{array}$ & 1.84 & .89 & 5.701 & .000 \\
7 & $\begin{array}{l}\text { Industry trainer uses trainees' } \\
\text { record book for evaluation }\end{array}$ & 1.79 & .78 & 1.886 & .112 \\
8 & $\begin{array}{l}\text { Industry trainer daily observes and } \\
\text { provides feedback }\end{array}$ & 1.79 & .91 & 3.997 & .003 \\
\hline
\end{tabular}

Items 1 to 8 , in the above Table 2 have been intended to know role played by industry trainer and commitment of enterprises in the implementation of cooperative training. To all items, group of respondents affirmed that it was moderate $($ Mean $<2.00)$. Even though items were differently rated by respondents, for all the above question items respondents gave negative responses $($ Mean $<2.00)$. This is the low level of mean score indicating that role played by industrial trainers and enterprises indicate that industries and industry trainers are discharging their responsibility below the expectation.

Specifically, as can be seen from item 1, industries are not adequately accepting trainees for cooperative training. The interview conducted with four outcome-based core process owners of sampled TVET colleges; also, reflect similar opinion about the lack of willingness of enterprises to accommodate trainees for cooperative training. However, four sampled industry representatives replied that the problem was lack of continuous communication and TVET collages were not regularly visiting industries before and during cooperative training. Contrary to this, one college Dean during FGD says that: "To me the major challenge in the implementation of cooperative training is that mostly there is no willingness of enterprises to accept the trainees. Mostly, the trainees are not assigned in their proper occupation. Besides, industrial trainers are not performing the training duties as expected".

Moreover, as illustrated in Table 1, item 2, industrial trainers are not familiar with units of competencies identified in their own occupational standards, for they, mostly, do not prepare training plan, even though it was their responsibility as indicated on the cooperative training hand-books. They usually do not ask industrial trainers to plan the training together with TVET trainers, because of the fear to be rejected form getting cooperative training program for their trainees. As some respondents indicated industry people never allow them to enter to the cooperative training corner even during follow up and monitoring session. During interview session, three outcome-based process owners said that they attach the units of competencies with the list of trainees when they send trainees to cooperative training providers. But, industrial trainers do not check the integrity of TVET training and cooperative training. One of an outcome based process owner says, in this regard, that "Cooperative training is not properly implemented according to cooperative training guidelines. The availability of training contract and training plan was at a lower level or less than the expected. In this respect, the practice of using these documents for enterprise-based training was not satisfactory"

Concerning the implementation of cooperative training interview question was raised for industry representatives and more or less they replied the same responses which are stated as follows. Cooperative training providing enterprises were rarely visited by TVET trainers and TVET vocational counselors. This idea was supported by two college Deans. For Deans, the problem is related to transportation facilities because companies are very far from the TVET colleges. 
However, out many training fields: construction sites, cooperative training providing micro and small enterprises and garment factories was found to be better visited by TVET trainees and trainers than other fields of occupations. According to Regional TVET agency representative “...in TVET colleges there exists the annual plan to send trainees to industries together with performance data which indicates the number of trainees sent for cooperative training increased in number from time to time, even completed and signed performance evaluation formats are available. But nothing is attached to indicate trainees were trained in line with required united of competencies".

Besides, ANOVA test result confirmed that the existence of statistically significant perception difference among the respondents because P-value for all items except item 2, 5 and 7 is less than 0.05 . Turkey's HSD statistical analysis still shows the perception difference occurred between trainers (Mean $=1.49,1.50$, and 1.66) on the one side and leaders $(2.11,2.28$ and 2.14) respectively, on the other. This difference may occur due to trainers' proximity to the training activities [8].

Table 3. Challenges that hinder the implementation of cooperative training.

\begin{tabular}{ll|ll}
\hline \multirow{2}{*}{ No. } & Items & \multicolumn{2}{c}{$\mathbf{N = 2 0 0}$} \\
\cline { 3 - 4 } & & $\mathbf{N o}$ & $\mathbf{\%}$ \\
\hline 1 & Lack financial resources & 142 & 71 \\
2 & Lack of strong and well organized management & 150 & 81 \\
3 & Lack of commitment & 161 & 80.5 \\
4 & Lack of integration & 146 & 64.9 \\
5 & Lack incentive for industrial trainers & 138 & 69 \\
6 & improper assignment of trainees & 140 & 70 \\
7 & Trainees were not properly supervised & 128 & 69 \\
8 & Absence of training agreement & 46 & 70.8 \\
9 & underestimating the benefit of cooperative training & 151 & 67 \\
\hline
\end{tabular}

As indicated on table three above, $142(71 \%)$ respondents replied that lack of financial resources and operational difficulties was the major problem. Concerning operational difficulties, lack of appropriate technology; shortage of machinery, equipment's, raw materials, transportation facilities and poor monitoring and evaluation system were recognized as potential problems related to operational difficulties. Supporting this stated that under-funding is a structural problem in the TVET sector, particularly in the public system. Costs of TVET will remain high, if it is to be provided as center based training, which is still the predominant mode of TVET delivery in Ethiopia. As with most other countries, public TVET programs in Ethiopia are usually more expensive than general education, requiring lower than average trainers/trainees ratio and substantial capital and recurrent expenses incurred through practical training. Thus, from this finding, it can be inferred that the budget allocated from the government were low that it partly satisfies the total requirement of the TVET sector. Apart from this, lack of experience and capacity to effectively and efficiently utilizing even the allocated small budget were also problem found to be important.

Lack of strong and well organized management system and problem of participating trainers and other stakeholders in planning, decision making and implementation are also major factor hindering cooperative training implementation. Other potential problems strongly pointed out by the majority of respondents 161(80.5\%), were lack of commitment. According to the respondents there was a great problem of commitment at all level starting from regional TVET leaders to trainers and trainees at grass root level, which were especially due to low understanding and awareness about the TVET program in general and cooperative training in particular. Regarding participation and coordination, most of the respondents (64.9\%), were lack of participation, communication, coordination and integration between stakeholders and TVET College. As a result, most of the concerned stakeholders were not actively and strongly participated in supporting, implementation and follow up of the cooperative training. According to the respondents, this has been reflected by low follow up, lack of support and resistance to participate in the implementation

Furthermore, $138(69 \%)$ replied that the industry trainers need incentives during cooperative training time. This was one of the problems that face in the implementation of cooperative training in the respected region. Regarding assigning trainee's majority of the respondents 140 (70\%), were some stakeholders not assign trainees on their training field. It was observed that they assigned trainees in other unrelated field.

Other potential problem identified by respondents, 46 $(70.8 \%)$, was the absence of training agreement between TVET college and industries. It was observed that there were no signed agreement between the college and industries. Without training agreement it was difficult to implement cooperative training. In supporting this [5], memorandum of understanding is a major reference document showing every role and responsibility of partners in cooperative training.

Other major challenges identified by most respondents, $151(67 \%)$, were lack of awareness and underestimating of benefit of cooperative training by concerned bodies. Thus, the above findings show that the stakeholders' awareness about the cooperative training was low. In supporting this, stated that in Ethiopia, as in many African countries, TVET suffers from a relatively poor public and stakeholder's image and awareness about the program. Lack of cooperation with enterprises is partly due to the absences of awareness about TVET programs. TVET graduates to successfully compete in the labor market so efforts should be made to increase stakeholders' awareness and know- how about the cooperative training. In supporting to the above findings, the interview conducted with TVET Agency officials, experts and TVET college deans reflected similar opinion about financial, operational, and managerial and issue of commitment were the potential problems.

\section{Conclusion and Recommendation}

Based on the international best practices, the Ethiopian Government has reformed the TVET system in 2008. However, the overall study result shows that the current 
TVET colleges in Oromia Regional State have been performing medium in making their respective colleges ready for cooperative training implementation. Furthermore, the low competence of TVET colleges to measure the actual skills needed in the labor market and planning trainings in terms of occupational categories hinders the effective utilization of market opportunities and causes fragile implementation of cooperative training. The study also identified that the weak collaborative work culture among TVET colleges and that of industries limits the opportunity of exploiting the potential of all stakeholders for the successful implementation of cooperative training. In addition, TVET colleges under the study did not adequately sorted out potential industrial partner and established full collaboration with them. As a result, TVET colleges did not reach the stipulated $70 \%$ workplace learning and are not successful in bringing about the expected output that would enable them to meet the expectation of respective stakeholders and win their commitment in its real sense.

Hence, to create and maintain close cooperation between the TVET colleges and stakeholders, it is recommendable that Oromia Regional State TVET agency; Zone and District TVET Departments including TVET colleges need to identify areas of training that constantly meet the expectation of industries, in a balanced way. And they should establish and maintain networks of partners for the delivery of cooperative training, feedback on the quality of TVET programs and facilitating the employment opportunity of TVET.

\section{References}

[1] MoFED, "Growth and transformation plan 2010/11 2014/15," Ethiopian Minstry of Finance and Economic Development, Addis Ababa, Annual 2010.

[2] Ethiopian Ministry of Finance and Economic Development, "Ethiopia's progress towards eradicating poverty: An interim report on poverty analysis study," Ethiopian Ministry of Finance and Economic Development, Addis Ababa, Interm 2012.

[3] Intenational Labour organisation, "Technical and vocational education and Training for the 21st Century," ILO, paris, Recommendations 2002.

[4] UNESCO, "Technical and Vocational Education and Training for Twenty-first Century: UNESCO and ILO Recommendations," UNESCO, Paris, Recommendation 2002.

[5] MoE, Labor market information system for TVET providers, 2010.

[6] Herschbach, VET management in the United States. Geneva, Sewizerland: ILO, 1995.

[7] MoE, National TVET Strategy, 2008.

[8] GTZ, Cooperative Training Handbook, 1st ed. Addis Ababa, Ethiopia: GTZ, 2007.

[9] Nielson, VET Management in Denmark. Geneva, Sewizerland: ILO, 1995.

[10] Oromia TVET, "National Annual Report," Oromia TVET, Addis Ababa, Annual 2014.

[11] Ministry of Education, "Anuual TVET Report," MoE, Addis Ababa, Anuual 2015.

[12] GTZ, Cooperative Training Handbook. Addis Ababa, Ethiopia: GTZ, 2007. 